\title{
The Efficiency of Palm Oil Fresh Fruit Bunches in West Pasaman, Indonesia (2010-2017)
}

\author{
Lisa Nesti ${ }^{\#}$, Firwan Tan ${ }^{\#}$, Endrizal Ridwan ${ }^{\#}$ \\ \# Departement of Economics, Faculty of Economics, Andalas University, Limau Manis, Padang, 26163, Indonesia \\ E-mail: lisanesti16@gmail.com,drfirwan@eb.unand.ac.id,eridwan@eb.unand.ac.id
}

\begin{abstract}
Palm oil production is important to the economic development of West Pasaman Regency (PASBAR) as most of its village population work in the agricultural sector, particularly in the field of palm oil plantations. The contribution of agricultural sector to Gross Regional Domestic Product (GRDP) is relatively large, approximately 46\%, the biggest in comparison with other sectors. Crude Palm Oil (CPO) is one of the main end products from Fresh Fruit Bunches (FFB) processing that is mainly purposed for export. The export of CPO in PASBAR is characterized by two functions, i.e., the exporting and the producing firms. CPO's factories own nearly all the exporting firms. This paper argues that there is unfair competition between exporting firms and agents or wholesales in buying FFB in the domestic market. The same misconduct occurs between agents or wholesalers when buying FFB from small collectors, who in turn, buy from palm oil farmers. The purpose of this study is to analyze the efficiency in marketing chains from exporting firms to palm oil farmers. The methods used are desk study, field survey, and questionnaires. The dynamic regression model is used as a quantitative approach. The research results indicate that marketing practice is not efficient as the purchasing prices received by palm oil farmers are low and inadequate. Several efficiency indicators determine it, i.e.: (i). Pbi<Mmi; (ii).Pbi+Ci > Pmi; (iii) FS average $60 \%$, its not close to $100 \%$ (iv) ME $>1$ (v) Et $<1$. This implies that the buying price of FFB is less favorable to palm oil farmers. Monopsony in FFB market is one of the main reasons this occurs.
\end{abstract}

Keywords - supply chain; monopsony market; marketing margin, marketing efficiency; price efficiency; price maker.

\section{INTRODUCTION}

The competitiveness of palm oil production has to be improved as much as possible not only for added values but also for increasing the income of palm oil farmers. It is essential because most of the village population in PASBAR work in the agricultural sector, particularly in sub-sector of palm oil plantations. Agricultural sector as a whole (farming and fishery) gives the most considerable contribution to the GRDP of PASBAR, compared with others sectors. Its contribution is estimated at $46 \%$ on average (based on 2010 price). From 2011 to 2015 , crop farming contributed to $26,24 \%$ on average, while food crops contributed to $10.07 \%$. These two sub-sectors play significant roles in the agricultural sector, particularly in sub-sector of Palm Oil. The second most substantial contribution to the GRDP of PASBAR is in the manufacturing sector with an average contribution of $16.41 \%$, followed by third rank in the wholesale and retail trade sector with an average contribution of $10.44 \%$, while construction, information, and communications only contributed respectively $5.43 \%$ and $4.97 \%$ (See Table 1) [1] - [3].
Crude Palm Oil (CPO) is one of the end products of fresh fruit bunches (FFB) after several steps of processing before being exported to the world market, (See Fig 1). Several issues are often posed by numerous experts such as the purchasing price of FFB at the farmer's market level is relatively low and inadequate. Besides, there is a significant discrepancy between prices received by the different parties involved in the supply chain namely farmers, agents or wholesalers and exporters. There are at least five answers to the above questions, i.e., the first answer is the weak bargaining position of palm oil farmers to wholesalers. This is due to the weak economic condition of palm oil farmers besides the delicate nature of FFB, which constrains them to sell their products to buyers close to them quickly. This condition is used by the agents or wholesalers to press the purchasing price of FFB on farmers. Similarly, the same reason is used by exporters to determine the prices of products they buy from wholesalers. It can be concluded that exporters of CPO are the ones who control the purchasing price of FFB in the domestic market; the second answer is that most exporters in PASBAR have their processing plants or factories of FFB to make intermediate CPO products. 
TABLE I

CONTRIBUTION OF EACH SECTOR TO GRDP OF PASBAR AT CONSTANT MARKET PRICE 2010, (2011-2015)

\begin{tabular}{|c|c|c|c|c|c|c|c|c|}
\hline \multirow[t]{2}{*}{ No } & \multirow[b]{2}{*}{ Sector of Activity } & \multicolumn{5}{|c|}{ Year } & \multicolumn{2}{|c|}{ Condition } \\
\hline & & 2011 & 2012 & 2013 & 2014 & 2015 & $\begin{array}{c}\text { averag } \\
\mathrm{e}\end{array}$ & Ranking \\
\hline \multirow[t]{9}{*}{1} & Agriculture, Forestry and Fishery & 47.06 & 46.7 & 46.08 & 45.65 & 45.08 & 46.11 & \multirow{9}{*}{1} \\
\hline & $\begin{array}{l}\text { 1.Agriculture, livesstock, hunting } \\
\text { and agriculture service }\end{array}$ & 40.24 & 40.05 & 39.58 & 39.07 & 38.28 & 39.44 & \\
\hline & a. Food Crops & 10,84 & 10,64 & 10,13 & 9,61 & 9,11 & 10.07 & \\
\hline & b. Horticultural Crops & 1,38 & 1,24 & 1,35 & 1,34 & 1.34 & 1.33 & \\
\hline & c. Plantation Crops & 26,13 & 26,3 & 26,29 & 26,37 & 26.13 & 26.24 & \\
\hline & d. Livestock & 0,86 & 0,86 & 0,82 & 0.79 & 0.76 & 0.82 & \\
\hline & e.Agriculture Service and Hunting & 1.03 & 1.01 & 1.00 & 0.96 & 0.94 & 0.99 & \\
\hline & 2.Forestry dan logging & 2.50 & 2.41 & 2.34 & 2.25 & 2.27 & 2.35 & \\
\hline & 3. Fishery & 4.32 & 4.24 & 4.16 & 4.32 & 4.53 & 4.31 & \\
\hline 2 & Mining and Quarrying & 1.48 & 1.48 & 1.47 & 1.47 & 1.47 & 1.47 & \\
\hline 3 & Manaufacturing & 16.38 & 16.42 & 16.40 & 16.48 & 16.35 & 16.41 & 2 \\
\hline 4 & Electricity and Gas & 0.02 & 0.02 & 0.02 & 0.02 & 0.02 & 0.02 & \\
\hline 5 & $\begin{array}{l}\text { Water Supply, sewerage, waste } \\
\text { management and Remediation Activities }\end{array}$ & 0.01 & 0.01 & 0.01 & 0.01 & 0.01 & 0.01 & \\
\hline 6 & Contruction & 5.18 & 5.23 & 5.43 & 5.53 & 5.76 & 5.43 & 4 \\
\hline 7 & Wholesale and retail trade & 10.22 & 10.28 & 10.44 & 10.59 & 10.66 & 10.44 & 3 \\
\hline 8 & Transportation and storage & 4.23 & 4.27 & 4.38 & 4.47 & 4.60 & 4.39 & \\
\hline 9 & Accomodation and Food Service & 0.45 & 0.45 & 0.45 & 0.46 & 0.46 & 0.45 & \\
\hline 10 & Information dan communication & 4.53 & 4.79 & 5.02 & 5.15 & 5.37 & 4.97 & 5 \\
\hline 11 & Financial and commucation & 1.70 & 1.75 & 1.77 & 1.77 & 1.77 & 1.75 & \\
\hline 12 & Real estate & 1.33 & 1.34 & 1.34 & 1.35 & 1.37 & 1.35 & \\
\hline 13 & Business activities & 0.05 & 0.05 & 0.05 & 0.05 & 0.05 & 0.05 & \\
\hline 14 & Public Administration & 3.89 & 3.69 & 3.57 & 3.44 & 3.43 & 3.60 & \\
\hline 15 & Education & 1.89 & 1.94 & 1.98 & 1.97 & 2.00 & 1.96 & \\
\hline 16 & Human Health and social work activities & 1.01 & 1.05 & 1.06 & 1.08 & 1.09 & 1.06 & \\
\hline \multirow[t]{2}{*}{17} & other service activities & 0.54 & 0.53 & 0.53 & 0.52 & 0.52 & 0.53 & \\
\hline & GRDP Total & 100 & 100 & 100 & 100 & 100 & & \\
\hline
\end{tabular}

This kind of business environment tends evidently to create a high dependency of agents/wholesalers to exporters and farmers to agents/wholesalers. This also implies the power of exporters in purchasing inputs (cq. FFB) in the local market. Exporters act both as the price makers in purchasing input (FFB) of CPO from the domestic market and as price takers when facing world market. The nature of FFB market system in the domestic market, which is in the condition of Vertical Integrated Market (VIM) so that the last buyers, i.e., exporting firms have the power to determine prices when purchasing FFB from farmers [10], [29], [9]. The long and considerable variation of the supply chain of marketing networks that increase marketing and marginal costs by decreasing the purchasing price of FFB at farmer level. FFB farmers do not have enough knowledge and technology to develop the derivative products of FFB. They cannot also develop their marketing network as an alternative channel to avoid dependency on buyers (See Fig.1).

Some related studies suggest that domestic CPO price is calculated based on the CPO world price of CIF Rotterdam minus Freight (shipping and insurance) and export tax while the amount of CPO export tax depends on export benchmark price. The world CPO price is often used as the basis for calculating the purchasing price of FFB by the palm oil factory [8]. It declines the export tax and its impacts on the export of Indonesian CPO to India [6]. The research reveals that the demand for exports of CPO by India, in the short term, is strongly influenced by the ratio between the price of soybean oil and the world CPO prices, while turn down in export tax to increase the volume of CPO exports significantly. Some factors influencing the domestic price of CPO in Indonesia by using econometric approach [4]. The result of this research shows that production volume, world price, export volume and domestic consumption have a significant effect on $\mathrm{CPO}$ price in the domestic market while import volume does not significantly influence CPO price. Indonesian $\mathrm{CPO}$ export shows that the domestic price of $\mathrm{CPO}$, the world $\mathrm{CPO}$ prices and the rupiah exchange rates to USD effect simultaneously and significantly Indonesian CPO exports while the rupiah exchange rates partially have no significant effect on CPO exports [5], [29]. It shows that the elasticity of price transmission from international $\mathrm{CPO}$ price to FFB prices in the domestic market (Padang Lawas' district) is considered relatively efficient [9]. This is indicated by the price elasticity equal to 0,98 or close to 1 (one), meaning an increase of global CPO prices at 1 percent resulting in increased prices of FFB also almost close by 1 percent at farmer level, implying that the marketing system of FFB to agents or wholesalers and exporters is relatively efficient in domestic market. [14], [10]. 
The price of FFB depends on the forces of supply and demand in the international market [29], [27]. However, the price at the level of self-employed farmers is strongly influenced by the determination of benchmark prices through the decision of the District Plantation Service, the co-integration between the price of vegetable oils and petroleum. This indicates that the world CPO price is the most influential variable in the long term to the vegetable oil market [4], [22]. The factors affecting Malaysian CPO prices by using dynamic systems has been analyzed [7]. The results show that Malaysian domestic $\mathrm{CPO}$ prices are significantly affected by local CPO production as well as world CPO and soybean oil prices. As [10] who researched price efficiency in the vertically integrated market of industrial natural rubber product in Indonesia, claims that imperfect market structure occurs in the domestic market of Indonesian natural rubber through inefficient price in the buying of raw rubber (slab) from farmers. This is proved by the cases in three Regencies of the study taken as the representative samples, i.e., North Sumatra, South Sumatra, and Jambi Provinces. The study reveals that pricing efficiency is relatively good in North Sumatra and South Sumatra but bad and extremely unfavorable for natural rubber farmers in Jambi. This indicates that natural rubber farmers are in a condition relatively favorable when dealing with agents or wholesalers and exporters in North Sumatra and South Sumatra as compared with those in Jambi Province.

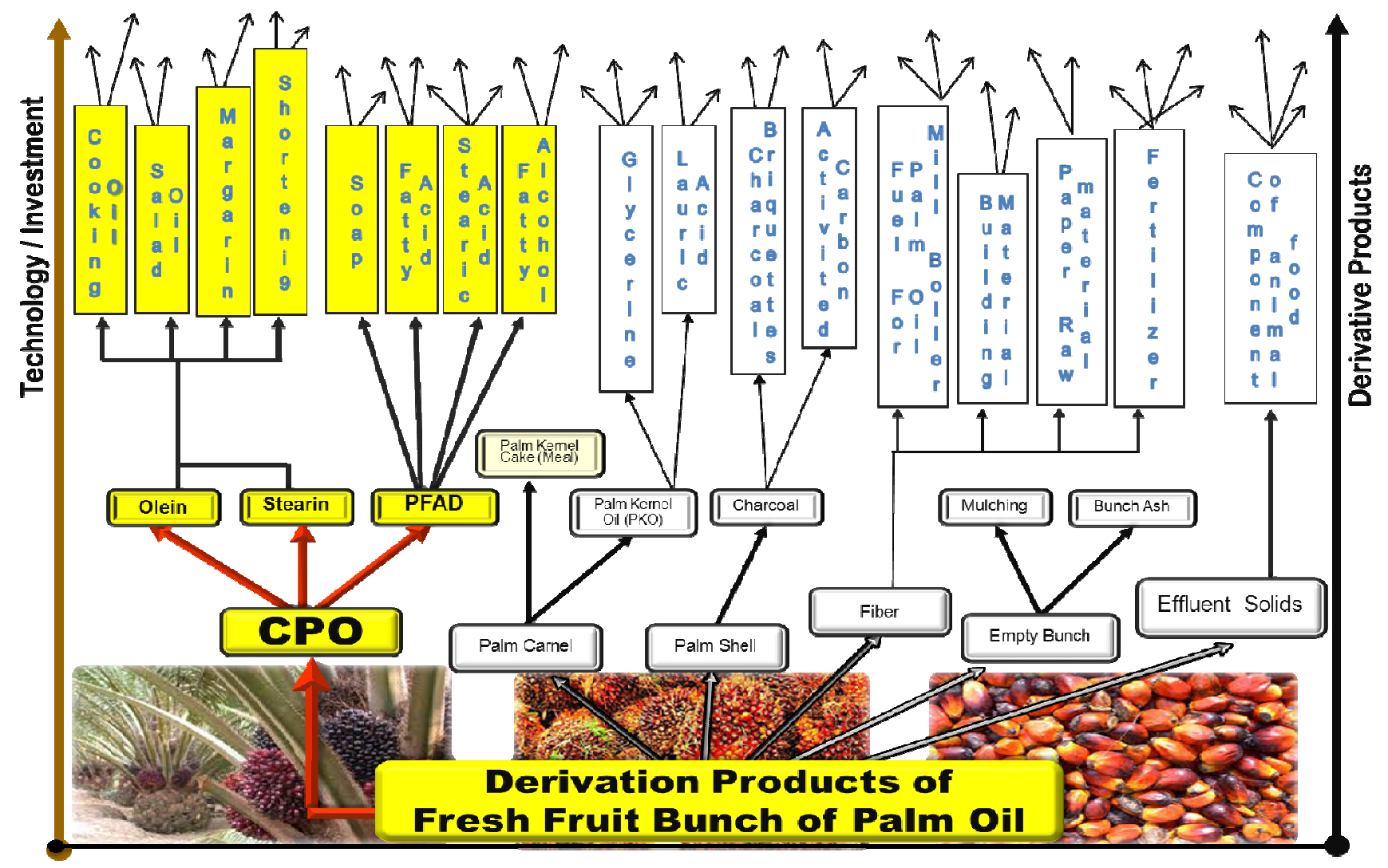

Fig.1 Fresh Fruit Bunches Derivation Products

A study revealed the volatility of world market prices and domestic market prices at the farmer, wholesaler, and retail levels by analyzing a coefficient of variation of the three Indonesian food commodities, i.e., rice, corn, and soybean, using time series data of 1990-2008 [11]. This shows that change of prices in the world market is not always immediately followed by changes in prices in the domestic market especially prices at farmer level. This is due to government policy intervention in the domestic market in term of imposing necessary pricing policies or often called government policy of purchasing price at the farmer's market level. It aims to analyze the Indonesian Crude Palm Oil (CPO) export performance [29]. There are two main aspects studied: the competitiveness of Indonesian CPO product in the global market and the Indonesian CPO export volume growth (dependent variable) on its correlation with specific variables (independent variables),i.e., world CPO prices, CPO domestic production, rupiah exchange rate to USD including residual variable. Data observation is quarterly where $\mathrm{n}=104$ (1990Q1-2015Q4). In this framework, two primary tools of analysis are used, i.e. (1) Revealed Comparative Advantage Index (RCA-Index), and (2) Regression Estimation equipped with Error Correction Model (ECM). The overall results of the study indicate that Indonesian CPO export performance within (1990Q12015Q4) is relatively fluctuant, unstable and less competitive from year to years.

Some research findings reflect facts. Most of the RCAIndices during the period of study are less than one. Thus the competitiveness of Indonesian CPO exports in the world market during 1990 Q1 to 2015Q4 was not strong if compared with competitiveness forces of world CPO exports 
or other exporting countries. The Indonesian CPO export volume growth during the period (1990 Q1-2015 Q4) was less responsive to the change of independent variables. The CPO world price and the rupiah exchange rate to US dollar variables are found in negative correlation with and have significant effects on Indonesian CPO export volume growth at different magnitudes both in the long and short-term. The internal CPO production variable is in positive correlation and has significant effects on Indonesian CPO export volume growth at different magnitudes in long and short terms. The coefficient regression residual variable (ECT) is in negative correlation and has significant effects on Indonesian CPO export volume growth at different magnitudes in the long term. The negative sign of ECT coefficient indicates a low rate of adjustment in the short term toward an equilibrium condition for the long term. Overall, independent variables influence significantly dependent variable in the short and long term.

This study hypothesizes that the condition of imperfect competition is likely to occur among CPO's export firms regarding purchasing FFB at the farmer's market level. The marketing chains from farmers to intermediate traders to CPO's export firms are considered not efficient. Before any policy recommendation, it is necessary to understand clearly the factors which influence the efficiency of marketing along the supply chain of FFB market from the farmer level to agents/wholesalers and exporter of CPO accordingly. Therefore, the objective of this study is to analyze the marketing efficiency of the supply chains from palm farmer market level of FFB to intermediate traders or agents or wholesalers and then to exporters of CPO in the local market of PASBAR in West Sumatra.

\section{MATERIAL AND METHOD}

\section{A. Definition of Efficiency}

In microeconomic theory, efficiency is defined as the best input used in producing output. While in macroeconomic theory, the efficiency refers to Pareto optimal conditions, i.e., an economy where no one party can be better without harming the other party [15]. The concept of efficiency is used as a criterion in the assessment of how well the market to allocate resources. As in [16] the efficiency of an industry is to produce output maximum using the input in a certain amount, or the ability of an industry to produce a specific output by using minimal input. A production method can be said to be more efficient than other methods if those methods to generate a higher added value at the same amount of sacrifice.

Some of the literature studied shows that there are three types of efficiency. Technical efficiency is achieved when a firm produces at the amount indicated by the production function or below the opportunity cost for the resources its uses. It produces the output at the minimum marginal cost curve when a firm produces at a technically efficient output level. The technical efficiency is that the relative ability of a business unit to obtain the maximum output by using a certain amount of input on the level of a particular technology. Allocative efficiency is a state of the economy in which production represents consumer preferences. In particular, every good or service is produced up to the point where the last unit provides a marginal benefit to consumers equal to the marginal cost of producing. The allocative efficiency is that the ability of business units to use optimal input at a relatively inexpensive price, at the level of the marginal product value is equal to the marginal cost. Economic efficiency implies an economic state in which every resource is optimally allocated to serve each or entity in the best way while minimizing waste and inefficiency. Any changes made to assist one entity will harm another when an economy is economically efficient

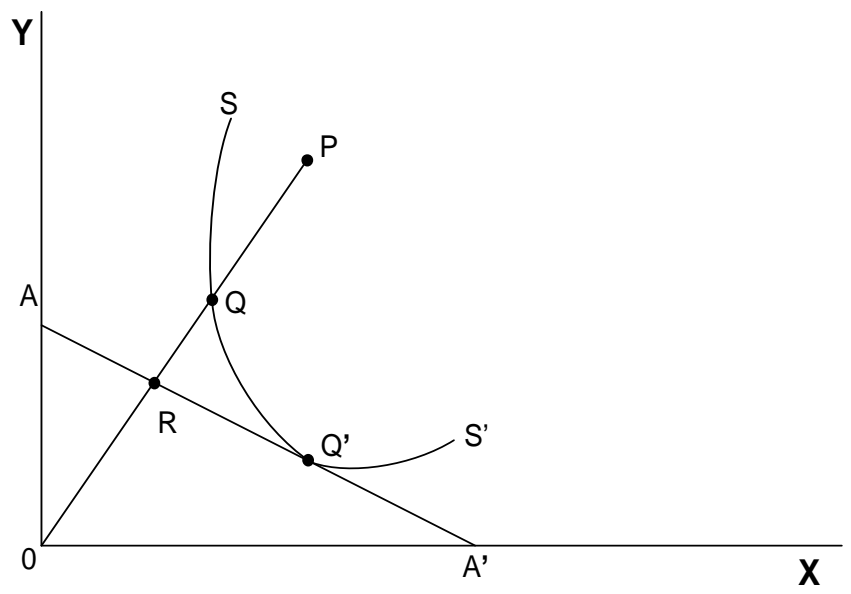

Fig. 2 Technical and Allocative Efficiency

Therefore, economic efficiency refers to pricing efficiency, i.e., the capacity of the system to affect and to prompt a reallocation of goods and services to maintain the consistency between what would be produced and demanded. The illustration of relationships among those three kinds of efficiencies can be seen throughout Fig.2. The curve of SS' is an isoquant curve. Supposed that a company is engaged at the point $\mathrm{P}$, then a straight line from $\mathrm{P}$ to 0 cuts the curve SS' at Q. Thus QP implies the excess use of production factors to the use of the most efficient production factors because QP is outside of isoquant line SS'. Technical efficiency is in this case equal to OQ/OP. The lines $\mathrm{AA}^{\prime}$ is the price line, often called in microeconomic theory as a "budget line" which shows the locus of combinations of input use ( $\mathrm{x} \& \mathrm{y})$. While $\mathrm{R}$ is the point of allocative efficiency, at $\mathrm{R}$ is efficient in generating the maximum output but not yet economically efficient.

\section{B. Market Structure and Efficiency}

Neo-classical economists believe that price is the leading indicator which can reflect the level of efficiency of a market. The level of market integration can be used as an indication of the efficiency of which is formed between the two or more markets interact, either vertically or horizontally [18]. Market integration is a measure that indicates how far the changes in the market price of reference would lead to changes in market followers. Thus the analysis of market integration is closely associated with the analysis of relationships between market structure and market conduct and market performance.

In many theories of industrial organization and economics, these three aspects are often called as "S-C-P model" (structure-conduct and performance model). The reasons are 
that the conditions of market structure influence simultaneously the condition of market conduct and market performance. Thus, these three aspects cannot be separated from each other in the process of determining price efficiency or marketing efficiency [19]. Market integration can be classified into two types,i.e., integrated vertical market system and horizontally integrated market system. Vertical integration is the incorporation process and function of two or more marketing agencies in the distribution stages into one system management.

Meanwhile, horizontal integration is the merger of two or more marketing agencies that perform the same function at the same stage of distribution as well into a single management system [20]. Price transmission from producer to the wholesaler is asymmetric both in the long and short run; Vertical Price Transmission from producer to retailer is asymmetric in the short run, but is symmetric in the long run; from wholesaler to the retailer is symmetric in the short run, but is asymmetric in the long run [21]. Grain Price and Volatility Transmission is from International to Domestic Markets [26]. Concentration and Competition in Dual Banking Industry. A Structural approach of price efficiency can be analyzed through the presence or absence of integrity of the market between the market benchmark with a market follower [13]. In this study, it is as a market follower is a market at the farm level while the market benchmark is the market at the level of the exporter as the final users or consumers.

Two levels of the market are said unified (integrated) if changes in one market to another market distributed proportionally. In a perfectly competitive market structure, changes in the market price of reference will be distributed in a perfect condition (100\%) to market followers at the farm level. In the long term commodity prices tend to rise due to rising consumer demand. However, the rate of increase in final consumer prices or final user prices may differ from the rate of price increases at the farm level, and depending on the behavior of traders in the conduct of the consumer price transmission to farmers. In perfectly competitive market traders will continue to make every rise in prices at the final consumer level with relatively similar magnitude to farmers, in other words, the price increases at the final consumer level is relatively equal to the price increases at the farm level. Nevertheless, in the market with monopsony or oligopsony power, price tends to increases at the farm level will be far less than the increasing price at final consumer prices due to the behavior of traders who tend to maximize profits by providing incomplete pricing information to suppress the purchase price from farmers [22].

\section{Supply Chains and Efficiency}

A company's Marketing Supply Chain is defined as a process and technology deployed for the purpose the development, production, and distribution of goods and services. In commerce, supply chain management, the management of the flow of goods and services, involves the movement and storage of raw materials, of work-in-process inventory, and of finished goods from the point of origin to the point of consumption. Studies show leading firms spend up to 35 percent of marketing budgets on the implementation of supply chain operations. A well-designed supply chain offers reliability, flexibility, and speed to market, yet only 20 percent of marketing supply chains are fully optimized. Therefore, even if we start out with an effective and optimized supply chain, however in running the business, it can grow unmanageable when a company creates new partners, new products, and new technologies. Partners may start to move the process toward their own end goal, not ours (See Fig 3).

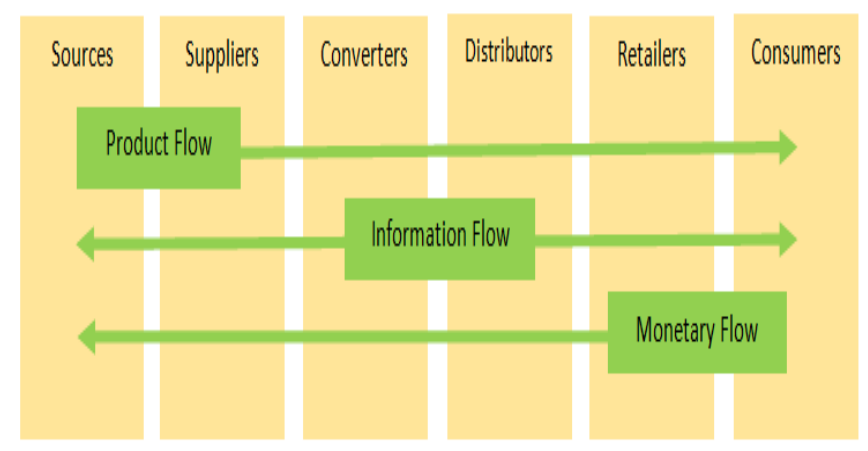

Fig. 3 Supply Chain Flows

\section{Some Related Formulas of Efficiencies}

1) Marketing Margin: Marketing margin is the difference between the consumer price level $\left(P s_{i}\right)$ at the producer's price level $\left(\mathrm{Pb}_{i}\right)$, or the sum of costs at each marketing agency [31]. It can be formulated as follows :

$$
\begin{gathered}
M M_{i}=P s_{i}-P b_{i} \text { where } M M_{i}=C i+\pi_{i} \\
C_{i}+\pi_{i}=P s_{i}-P b_{i} \\
\pi_{i}=P s_{i}-P b_{i}-C_{i} \\
T M=\sum M M_{i}
\end{gathered}
$$

Where:

$\mathrm{MMi}=$ Marketing Margin on the i-level market (IDR/Kg) $\mathrm{Ps}_{\mathrm{i}}=$ consumer price at the i-level (IDR / Kg)

$\mathrm{Pb}_{\mathrm{i}} \quad=$ Producer price at the i-level (IDR / Kg)

$\mathrm{Ci}=$ Marketing Cost at the i-level (IDR / Kg)

Mi = Profit at the i level of marketing chain (IDR / Kg)

$\mathrm{TM}=$ Total Marketing Margin in the year of study (2010July 2017) (IDR / Kg)

The decision criteria are as follows: If Pbi> MMi where the price at the producer level is higher than the marketing margin, thus the marketing system is efficient. If Pbi $<\mathrm{MMi}$ where the price at the producer level is smaller than the marketing margin then the marketing system is inefficient.

2) Profit Margin: Profit margins are the difference between marketing margins and marketing costs [31], can be expressed in the form :

$$
\begin{aligned}
& P M_{i}=\pi_{i}=M M_{i}-C_{i} \\
& P M_{i}=P s_{i}-\left(P b_{i}+C_{i}\right)
\end{aligned}
$$


Where :

$\mathrm{PMi}=$ Profit Margin on the i-level market (IDR/Kg)

$\mathrm{Ci}=$ Marketing Cost at the i-level (IDR / Kg)

The marketing system will be more efficient if the profit margin is more considerable, with criteria are: If $P b_{i}+C_{i} \leqslant P M i$ where the price of producer level and marketing cost is less than profit margin then the marketing system is efficient and If $P b_{i}+C_{i}>P M_{i}$ where the price of producer level and marketing cost is less than marketing margin then the marketing system is in,efficient

The statement can be proved by simulation as follows: Assuming that $P s_{i}>\left(P b_{i}+C_{i}\right)$ and $P s_{i}=$ constan, then $P M_{i}$ will increase if the value $P b_{i}+C_{i}$ is small. Example simulation: Suppose: $P b_{i}+C_{i}=a$, if a> 0 then $P M_{i}=P S_{i}-a . \quad$ If $\quad P b_{i}+C_{i}=a-1 \quad$ then $P M_{i}=P S_{i}-(a-1)=P s i-a+1$. So it can be proven that the profit margin is greater if the value $P b_{i}+C_{i}$ is getting smaller.

3) Farmer's Share: Farmer's share is the percentage of the price share for farmers from the selling price of the commodity at the consumer level. Whether or not the share received by the farmer is appropriate at a price paid the end consumer can be revealed through the following.

$$
F s=\frac{F p}{p e} \times 100 \%
$$

Which range $(0 \%<\mathrm{Fs} \leq 100 \%)$

Where:

Fs $=$ Farmer's Share in buying price of FFB offered by exporter-producer of CPO in the domestic market from 2010 to 2017 (\%).

$\mathrm{Pp}=$ Farmer Price (IDR/Kg), the price that received by the farmer of FFB

$\mathrm{Pe}=$ Price paid by exporter either to intermediary merchants or exporter has its owned plantation of Palm Oil in the domestic market (IDR/Kg)

As [32] stated that if the value of the percentage of farmer share approach 100 percent, it is called more efficient but if the percentage of farmer share approach to zero, it implies the condition of marketing activities are inefficient

4) Marketing efficiency: According to [33] that a marketing channel will be assessed efficiently if the marketing efficiency value is small from one (ME <1) and is said to be inefficient if the value of ME> 1 .

$$
M E=\frac{N V}{N V} x 100 \%
$$

Where:

$\mathrm{ME}=$ Marketing Efficiency (IDR)

$\mathrm{PV}=$ Total Cost (IDR $/ \mathrm{Kg}$ )

$\mathrm{NV}=$ Product Value/ Buying Price at exporter (IDR /Kg) The smaller the value of marketing efficiency the more efficient the marketing activities are undertaken.
5) Price Efficiency: The Ordinary Least Square Method (OLS). Time series data are needed to analyze the influence of price efficiency at exporter level to farmer level. The time series data tendency is shown on linear behavior. Therefore the model used is a linear-log model. The regression coefficient (gradient $=\mathrm{b}$ ) directly becomes the coefficient of elasticity. The nonlinear regression equation is expressed as follows:

$$
\begin{aligned}
& P_{p}=a\left(P_{e}\right)^{b}, \\
& \log P_{p}=\log a+b \log P_{e} \\
& \frac{\partial \log P_{p}}{\partial P_{p}}=\frac{\partial \log g_{a}}{\partial P_{p}}+b \frac{\partial \log P_{e}}{\partial P_{s}} \\
& \frac{1}{P_{p}} \frac{\partial P_{p}}{\partial P_{e}}=b x \frac{1}{P_{e}} \\
& \text { Et }=b=\frac{\partial P_{p}}{\partial P_{a}} x \frac{P_{a}}{P_{p}}
\end{aligned}
$$

The implication of the above calculation is: if Et $=1$ means the rate of change of price by $1 \%$ at the level of the exporter resulted in a change of $1 \%$ at the farm level and the marketing system that occurs is efficient. However, if Et $>1$ or Et $<1$ then the marketing system is inefficient. The rate of change of the price equal to the level of the exporter is not the same as the rate of change of the price at the farm level [28].

Although this simple linear regression model is easier to understand as the procedure is simple, the regression model is unable to explain the effect of a time lag as one of the parameters observed in the model. Price Efficiency can therefore be calculated by using the Error Correction Model (ECM) approach, since most of the economic analyses are closely related to time series analysis which is often manifested by the relationship between changes in an economic scale and economic policy at a time and its effects on symptoms and economic behavior at another time. The formulation of this kind of relationship in dynamic linear models has increasingly been attempted. Dynamic linear model to emphasizing the dynamic structure of short-term relationship (short run) is also emphatic on the behavior of variables in balance or in a long-term relationship. The long run of a model will be more critical as theoretical testing always focus on the long-term nature. The general model of ECM can be expressed as follows [23]:

$$
\Delta P p_{t}=\alpha_{0}+\alpha_{1} \Delta P \theta_{t}+\alpha_{2} E C_{t}+\varepsilon_{t}
$$

Where:

$E C_{\mathrm{t}}=P p_{t-1}-\beta_{0}-\beta_{1} P e_{\mathrm{t}-1}, \Delta P e_{\mathrm{t}}=P e_{\mathrm{t}}-P e_{\mathrm{t}-1}$

For non-linear regression, by entering logs into the equation, it becomes:

$$
\begin{aligned}
& \quad \Delta \log P p_{t}=\alpha_{0}+\alpha_{1} \Delta \log P e_{t}+\alpha_{2} E C_{t}+\varepsilon_{t} \\
& E C_{t}=\log P p_{t-1}-\beta_{0}-\beta_{1} \log P \theta_{t-1}
\end{aligned}
$$

Where:

$\Delta \mathrm{Pp}_{\mathrm{t}}=$ Difference from farmer-level price, 
$\alpha_{1}, \alpha_{2}=$ Short-term coefficient,

$\beta_{\mathrm{i}}=$ Long-term coefficient,

$\alpha_{a}=$ Coefficient of correction imbalance.

$\Delta \mathrm{P}_{\mathrm{e} \mathrm{t}}=$ Differences exporter level,

$\varepsilon_{\mathrm{t}}=$ Error term

The efficiency value shown by the elasticity value in the regression coefficient in the ECM equation can be described as follows:

$$
\Delta \log P p_{t}=\log a+b \Delta \log P e_{t}
$$

$$
\begin{gathered}
\frac{\partial \Delta \log P p_{t}}{\partial \Delta P e_{t}}=\frac{\partial \log g_{t}}{\partial \Delta P e_{t}}+b \frac{\partial \Delta \log P e_{t}}{\partial \Delta P e_{t}} \frac{1}{\Delta P_{p}} x \frac{\partial \Delta P_{p}}{\partial \Delta P e_{t}}=\frac{b}{\Delta P e_{t}} \\
b=\frac{\partial \Delta P p_{t}}{\partial \Delta P e_{t}} x \frac{\Delta P p_{t}}{\Delta P p_{t}}
\end{gathered}
$$

$\alpha_{2}$ Imbalance correction coefficient is an absolute value that explains how quickly the time required to obtain a balance value. If the probability value of the coefficient $\alpha_{2}=$ is smaller 0.05 then there is a short-term relationship.

\section{E. Assumptions In ECM}

In determining the linear regression model through the ECM approach, there are several assumptions, can be described as follows:

1) E1. Stationary Test: In making econometric models of time series data are required to use stationary data. If the data used is not stationary means that the data has autocorrelation or heteroskedasticity it will lead to an inferior model that is estimated and will produce a model known as spurious regression (spurious regression). Test stationarity data using the test "Unit Root Test" or unit root test (Dickey and Fuller or DF)

$$
\Delta P_{p_{t}}=\delta P_{p_{-1}}+s_{t}
$$

with hypothesis:

$H 0: \beta=0$

$$
H 1=\beta \neq 0
$$

Statistics test given to test the above hypothesis is:

$$
\tau=\frac{\beta}{\sec (\theta)}
$$

Criteria for testing the hypothesis above are: $\mathrm{H} 0$ is accepted if $\tau>\mathrm{DF}$ statistical value is said $\mathrm{Yt}$ is not stationary $\mathrm{H} 0$ is rejected if $\tau<\mathrm{DF}$ statistic value is said $\mathrm{Yt}$ stationary

2) Integration Degrees Test: The integration degree test is performed when the data is not stationary at the stationary test time. The integration degree test is intended to know to what degree the data will be stationary. In cases where the data used is not stationary
3) Cointegration Test: Cointegration test is a continuation of unit root test and integration degree test. The cointegration test is intended to test whether the residual regression produced is stationary or not. In the case of one or more variables having different degrees of integration, they cannot cointegrate

Hypothesis test used is:

$\mathrm{H} 0: \mu=1$, meaning there is no cointegration

$\mathrm{H} 1: \mu \neq 1$, meaning there is cointegration

If the observed variable forms a mutually cointegrated set, then the corresponding dynamic model is the ECM model. Furthermore, the error correction model becomes a valid model when the cointegration variables are supported by significant Error Correction Term (ECT).

\section{F. Types and Sources of Data}

The research was conducted in West Sumatra, Indonesia by using primary and secondary data. Purposive sampling is used as the statistical tool. The Regency of PASBAR is considered as a relevant region of the study since it is one of the most significant areas of palm oil plantation in West Sumatera Province. Primary data was obtained through interviews with the unit of analysis, i.e., palm oil farmers, collectors, and mills (factory leaders of CPO). This data is aimed to identify the market behavior or business actors behavior in producing and marketing activities in marketing chains from palm oil farmers to agent or wholesalers and exporter-producer of CPO.

Interviews were also conducted with two related leaders of associations, i.e., the Indonesian Palm Oil Association and the Indonesian Palm Oil Association. Other interviews were conducted with leaders of Plantation Office of West Sumatra. Secondary data was obtained principally from several government institutions such as Central Bureau of Statistics, West Sumatra Plantation Office, West Sumatra Trade, and Industry Office, West Sumatra Custom office, also from the mass media and related online media with palm oil plantation and trading. This research uses the analysis approaches in term of quantitative and descriptive analysis. The data used in this study are monthly time series data starting from the year of 2010 to July 2017, which means that the number of observations equals $90 \quad(n=90)$. Secondary data includes selling prices at FFB farmers, agents or wholesalers and CPO at exporter level (export selling prices).

The data were analyzed in two steps. The first step is to identify the current supply chain system of FFB and CPO in PASBAR, mainly supply chain from farmers of palm oil to the agents or wholesalers and producer-exporters of CPO. In this context, the marketing chains from farmers of palm oil to the buyers, i.e., producer-exporters are analyzed deeply. The objective of the analysis is to evaluate the rate of efficiency in each level of trading process from farmers to exporters of CPO in West Sumatra. For that purpose, a field survey was necessary to interview each actor in each level of the supply chain of FFB to buyers of FFB and producerexporters of CPO. The process consists of three parts, i.e., mapping the core processing in the supply chains, mapping 
the principal actors involved in the supply chains and their activities, mapping of material, money and information flow.

The flows of goods and services in the palm oil supply chain consist of flows from palm oil farmers to agents or wholesalers and to producer-exporters who manufacture FFB to get the final products for export in the form of CPO. The benefits exist at each step of marketing activities. There is a flow of money and information and services that exist at the level of farmers when the agents or wholesalers buy FFB, and also the same model exists when producer-exporters buy FFB from agents or wholesalers. FFB is delivered to the factory of producer-exporters to be manufactured into CPO. The flow of information is a controller for managing goods and services flows that occur in the palm oil agro-industry supply chain.

The second step is to examine the rate of marketing efficiency during the period of study (2010-2017). Since the market of FFB in PASBAR is in the condition of the vertically integrated system, therefore, to obtain evidence about the efficiency of markets and prices, econometrical testings are needed. Data processing is done by using "Software Eviews," which comprises "time series data" with observation $\mathrm{n}=90$ from 2010 to July 2017 to know data specifications. Stationary analysis of data with the unit root test models ADF (Augmented Dickey-Fuller) is used. If the result of the stationary test shows that the data is stationary, the analysis of the estimation model can be carried out, and if the data found is otherwise, then the examination can be continued to obtain a stable level.

Co-integration test is used to determine whether or not the data is in the model co-integrated. If the results of testing show that there is no co-integration in the regression equation model, then the model can be used to estimate the values of variables in an equation. However, if it is found that co-integration exist in the model, then the problems of co-integration can be corrected by using the ECM, which is the other variable or residual variable considered as a control variable that expresses the process of adjustment to achieve the equilibrium condition in the long-term

\section{RESULT AND DISCUSSION}

\section{A. The efficiency of Existing Supply Chains}

From the field survey in PASBAR, it was found that 14 factories are producing $\mathrm{CPO}$ with a total production of estimated to $475.770,09$ tons/ year. FFB is planted in four types of land ownership (Government Owned Enterprises, Private Owned Enterprises, Plasma Enterprises, and FarmerOwned Enterprises). Land owned by the government is estimated at $3.246 \mathrm{Ha}(57 \%$ productive land and $43 \% \mathrm{Ha}$ nonproductive land). Meanwhile, private land is estimated at $58,290 \mathrm{Ha}(57 \%$ productive land and $43 \%$ non productive land), Plasma land equals to $21,047 \mathrm{Ha}$ (57\% productive land and $43 \%$ non productive land) and Farmer land or often referred to as the independent farming ranges to $80,855 \mathrm{Ha}$ (75\% productive land and $24,6 \%$ non productive land) with 76,134 farmers.

Total Production of FFB from PASBAR is about $2.378 .850,45$ ton/year which came from $1,9 \%$ production of government land, $34,5 \%$ production of private land, $12,4 \%$ production of plasma land and 51,2\% production of farmer land [3], [2].

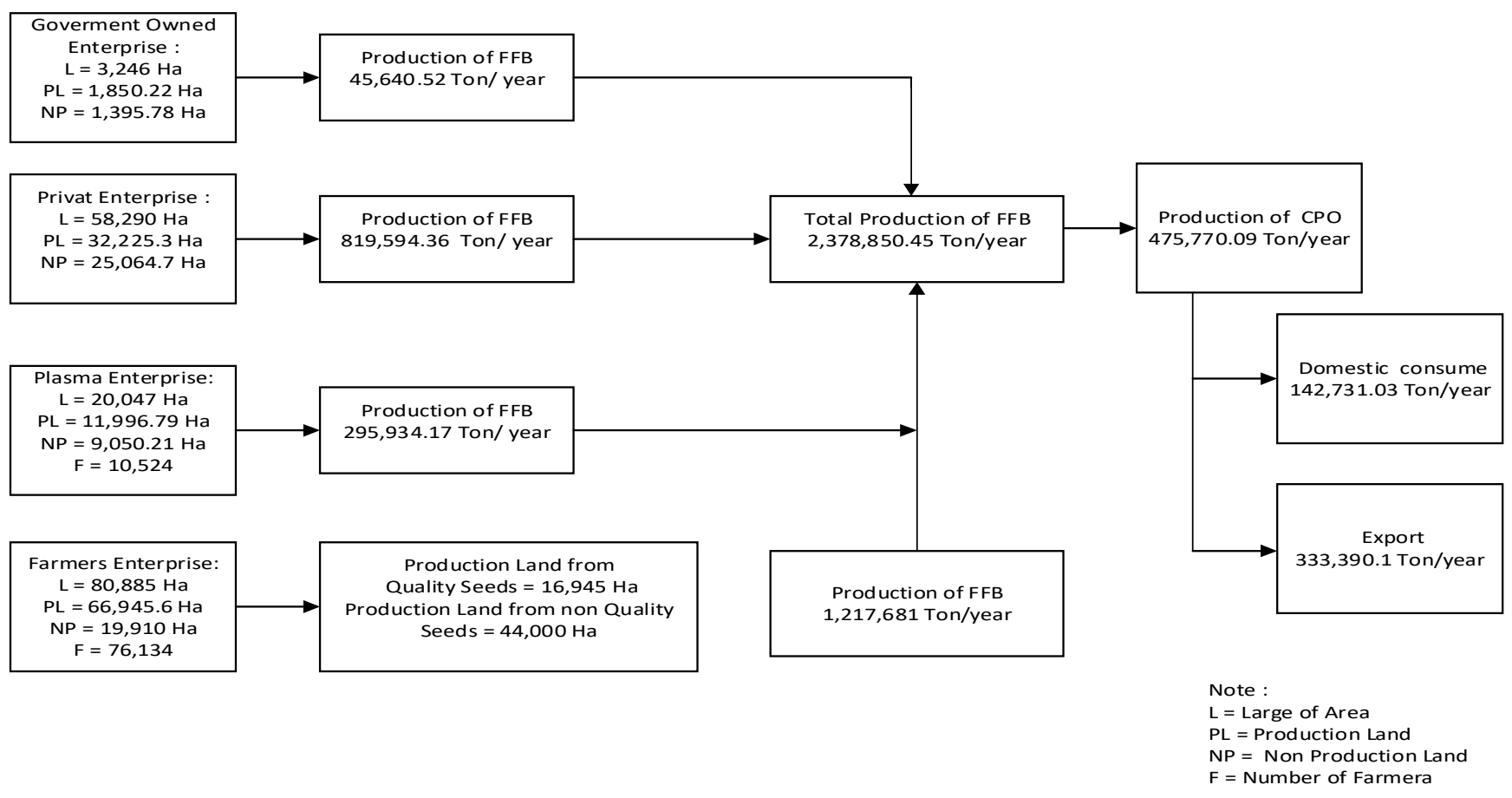

Fig. 4. Production of FFB and CPO in West Pasaman

The field survey results related to the supply chain is one of the oil palm plantations in PASBAR reflect the general condition of the supply chain in the Regency of West
Sumatra. This district is one of the largest palm oil producers compared to other districts in West Sumatra palm oil plantation that is estimated at $96.583 \mathrm{Ha}$ with a total 
production of 223.890 tons in 2013 [3]. The flow of palm oil supply chain from farmers in PASBAR is lengthy and complicated (see Fig.5). The commodity supply chain network of FFB involves several actors namely farmers, small collector, collectors large and palm oil mills. In the supply chain, there are three streams FFB observed that: The flow of goods, information, and money. Supply FFB flow of goods starts from the farm owned by small farmers that are sold to collectors.

There is no bargain price; collectors accept the price set by the factories and farmers receive a price set by collectors. Fig. 6 shows the selling price of FFB to each actor in the supply chain in PASBAR in February 2017. The year flow of information on FFB starts by the purchasing price set by mill FFB, which is communicated to farmers through cooperative partners. Meanwhile, the purchase price of the FFB between the companies and the cooperative is set by the Plantation Office of West Sumatra Province Plantation.

During the field survey, the selling price of FFB from plasma farmers to the factory amounted to IDR.1, 889 / Kg. This price is a mutually set between the factories and the plasma farmers by the Plantation Office of PASBAR, while the factory buys FFB of large collectors at IDR 1,438 / Kg, who in turn buy FFB from small collectors IDR.1,300 / Kg. Consequently, the price of FFB from farmers to small collectors is fixed at IDR.1,192/Kg. On the other, palm oil factories to sell CPO abroad at a price of IDR $8,120 / \mathrm{kg}$. This means that the selling price of FFB at the level of farmers is the lowest among FFB supply chain (see Fig.6).

On the one hand, it can be seen that farmers do not have the power to bargain the selling price of FFB to collectors, who, on the other hand, are unable to bargain selling price with the factories. Therefore, the factories act as the price makers in the domestic buying price. The weak bargaining position of farmers is mainly due to the low yield of FFB farmers as a result of lousy seed quality, the remoteness of the farming areas, and the fact that most farmers are indebted to the collectors, so they have no choice but to accept the price set by them. Sometimes, many of the farmers return home with nothing because they paid off debts (see Fig.6). On one side is seen Farmers do not have the power to bargain the selling price of FFB to collectors and on the other side collectors also do not have bargaining data to the factory. Here the factory acts as a price maker against the domestic buying price of FFB. The analyzed causes of the occurrence of a weak bargaining position are the farmer for several reasons. They are the low yield of FFB farmers as a result of seed quality is not good, the distance between the orchard farmer and the collector is quite remote, and small capital resulting in more length supply chain to be taken by the farmers.

Most of the farmers are already in debt to the collector, so there is no choice from the farmers to accept the price set by the collector and cut the money earned from the sale of FFB to pay off its debt, FFB Scales played by collectors and cuts, Other pieces that must be paid by farmers.
So the net receipts received by farmers are very small even many of the farmers who do not get money after selling his FFB because they have to pay a debt to the collector.

It can be seen, from these figures, that palm oil mills that produce CPO for exported are the ones who receive a considerable margin profit. This condition displays an inefficient market where CPO producers, as well as CPO exporters, enjoy enormous profits from FFB's purchase price at the expense of farmers after deducting variable costs. Most of the palm oil processing factories in West Pasaman Regency are subsidiaries of a giant palm oil companies not only in Indonesia but also in the world, such as PT. Wilmar, PT. Musimas and PT. Incasi Raya. The establishment of palm oil subsidiaries in several districts of West Sumatra is aimed to avoid significant taxes and to manage and anticipate incoming invoices from subsidiaries so that the purchase price of FFB farmers can be suppressed as cheaply as possible, which only benefits the giant CPO companies.

\section{B. Marketing Margin, Profit Margin, Farmers Section and Marketing Efficiency}

One of the determinants of supply chain success is knowing marketing efficiency. A marketing system is said to be efficient if it succeeded in marketing goods from producer to consumer with the lowest cost and able to do a fair share of the total price paid by the last consumer to the parties involved in the production and marketing activities. Calculations Marketing efficiency can be seen by marketing margins, profit margins, farmers' share, marketing efficiency and price elasticity.

1) Marketing Margin: The marketing margin of FFB in West Pasaman is divided into three parts, namely the marketing of farmer FFB to small collectors, from small collectors sold to large collectors and from large collectors to processing factories. Based on Table 2, the marketing margin of each segment is obtained from marketing margins from farmers to small collectors ranging from IDR 200 to IDR.350/year with observations from 2010 to 2017. The marketing margins from small collectors to large collectors range from IDR 200 to IDR.300 while the marketing margin of large collectors ranges from IDR. 200 to IDR.300.

The decision criteria are as follows: If $\mathrm{Pbi}>\mathrm{MMi}$ where the price at the producer level is higher than the marketing margin, thus the marketing system is efficient. If Pbi $<\mathrm{MMi}$ where the price at the producer level is smaller than the marketing margin then the marketing system is inefficient.

It can, therefore, be seen that the FFB processing firms obtain the most significant marketing margin. In these circumstances, the FFB market in West Pasaman is inefficient, even though the price at the level of a farmer, small collectors, and massive collectors levels is efficient. 


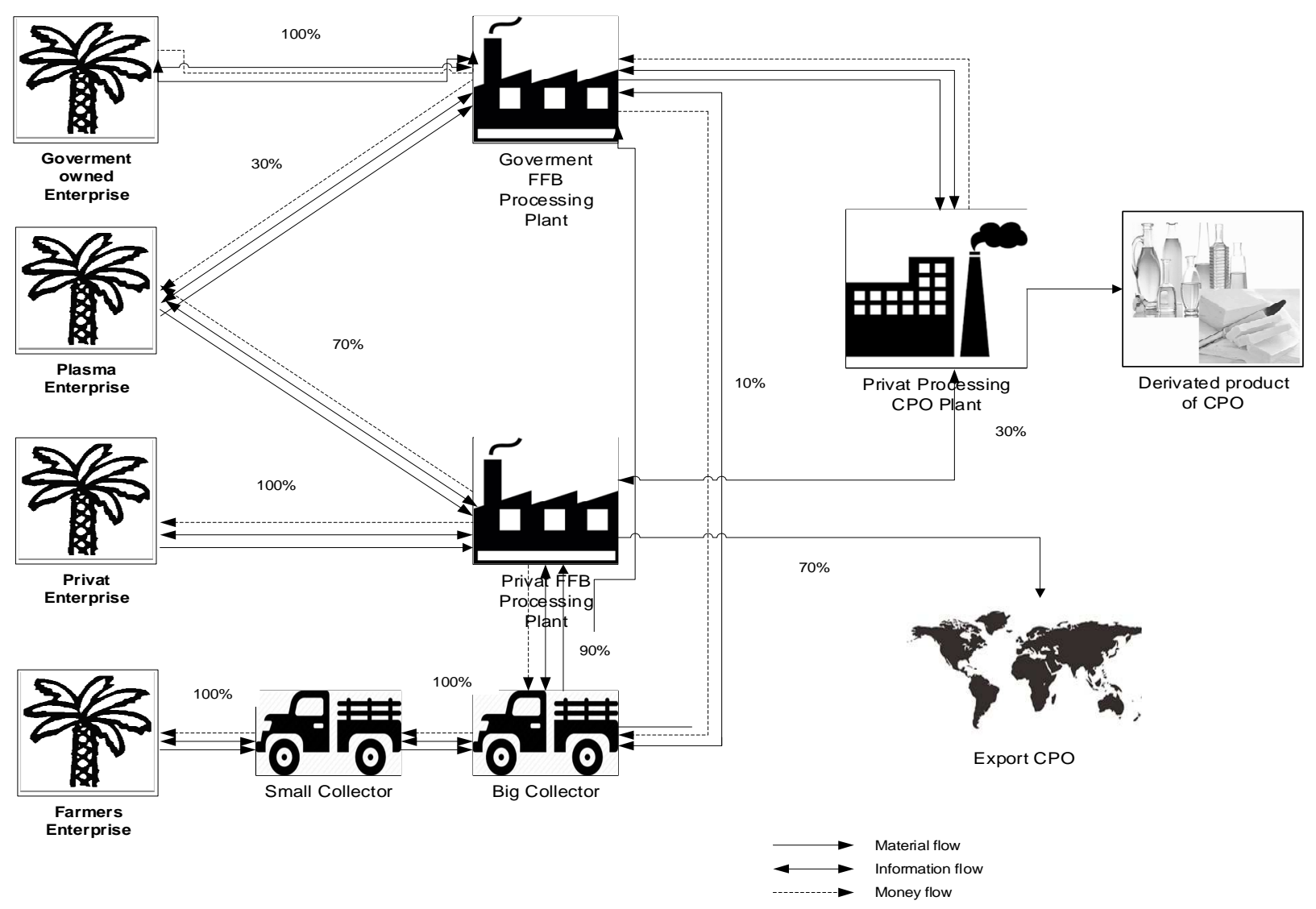

Fig 5. Diagram of Supply Chains of FFB \& CPO in West Pasaman Regency of West Sumatra Province

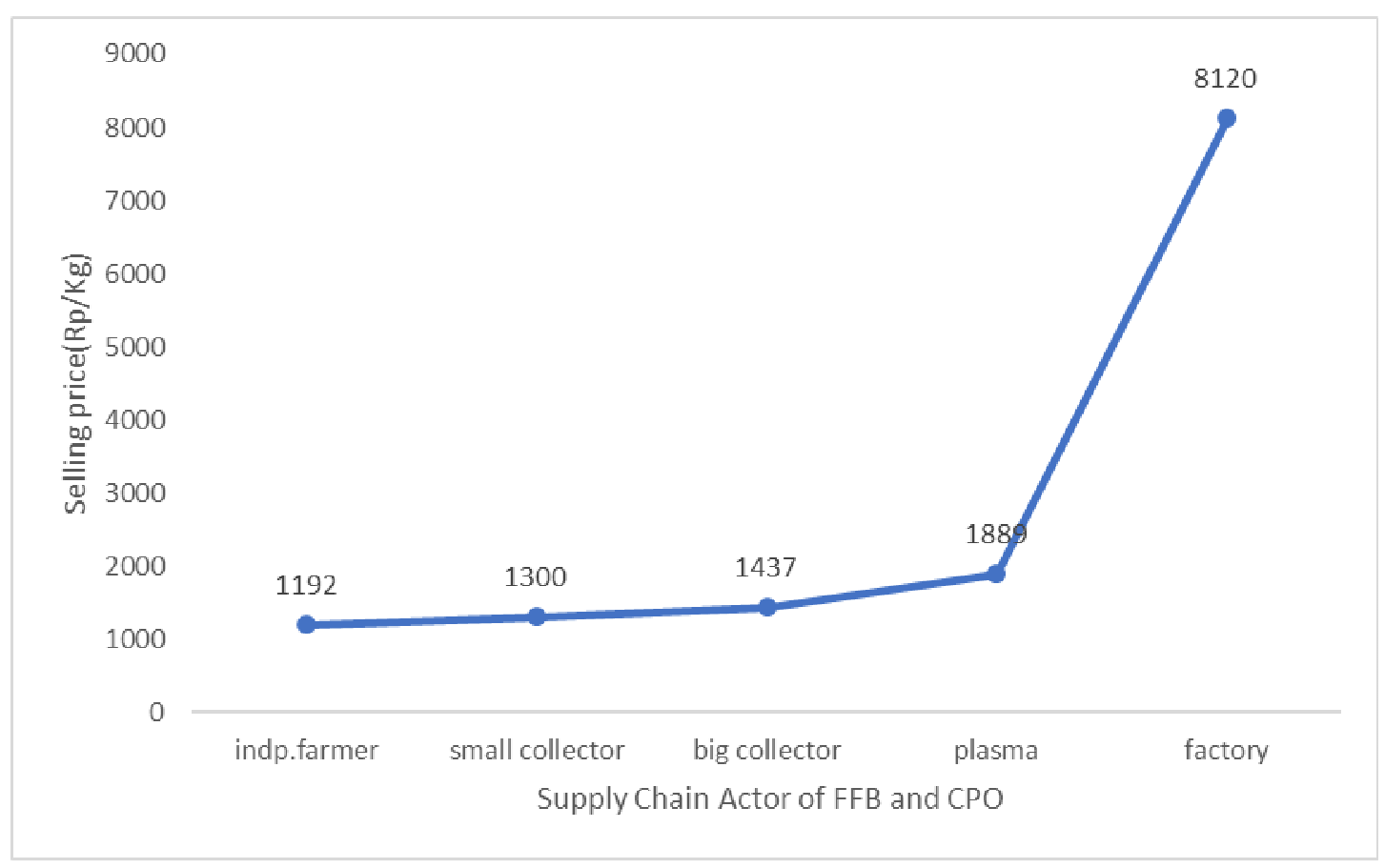

Fig 6. Supply Chain Actor of FFB and CPO 
TABLE II

Marketing Margin, MARKeting EfFiciency OF FFB in West PASAMAN In 2010- July 2017

\begin{tabular}{|c|c|c|c|c|c|c|c|c|c|}
\hline Marketting Activities & measures & 2010 & 2011 & 2012 & 2013 & 2014 & 2015 & 2016 & 2017 \\
\hline \multicolumn{10}{|l|}{ Farmers } \\
\hline Selling Price of FFB & $\mathrm{IDR} / \mathrm{Kg}$ & 830.41 & 997.89 & 817.09 .00 & 726.83 & $1,016.27$ & 705.76 & $1,231.24$ & 907.69 \\
\hline $\begin{array}{l}\text { Cost ( seeds, fertilizers, } \\
\text { insecticides) }\end{array}$ & IDR/Kg & 100 & 110 & 115 & 120 & 122 & 125 & 128 & 230 \\
\hline Wage of Harvesting & $\mathrm{IDR} / \mathrm{Kg}$ & 200 & 220 & 230 & 250 & 270 & 280 & 290 & 250 \\
\hline Depreciation & $\mathrm{IDR} / \mathrm{Kg}$ & 24.91 & 29.94 & 24.54 .00 & 21.08 & 30.49 .00 & 21.17 & 36.94 & 27.23 .00 \\
\hline Profit Margin & IDR/Kg & 505.50 & 637.95 & 448.36 & 335.03 & 593.78 & 279.50 & 776.30 & 400.46 \\
\hline Farmer share & $\%$ & 67.49 & 70.38 & 63.26 & 58.77 & 64.88 & 54.05 & 65.45 & 58.27 \\
\hline \multicolumn{10}{|l|}{ Small Collector } \\
\hline Buying Price of FFB & $\mathrm{IDR} / \mathrm{Kg}$ & 830.41 & 997.89 & 817.09 .00 & 726.83 & $1,016.27$ & 705.76 & $1,231.24$ & 907.69 \\
\hline Wage of Labor & $\mathrm{IDR} / \mathrm{Kg}$ & 100 & 120 & 150 & 160 & 170 & 180 & 190 & 200 \\
\hline Transportation cost & $\mathrm{IDR} / \mathrm{Kg}$ & 20 & 22 & 26 & 28 & 33 & 34 & 36 & 38 \\
\hline Depreciation & IDR/Kg & 30.912 & 35.937 & 32.037 & 29.605 & 39,4881 & 30,1728 & 47,4372 & 37,7307 \\
\hline Selling Price of FFB & IDR/Kg & 1030,41 & $1,197.89$ & $1,067.9$ & 986.83 & $1,316.27$ & $1,005.76$ & $1,581.24$ & $1,257.69$ \\
\hline Profit Margin & $\mathrm{IDR} / \mathrm{Kg}$ & 49 & 22 & 42 & 42 & 58 & 56 & 77 & 74 \\
\hline Marketting Margin & $\mathrm{IDR} / \mathrm{Kg}$ & 200 & 200 & 250 & 260 & 300 & 300 & 350 & 350 \\
\hline \multicolumn{10}{|l|}{ Big Collector } \\
\hline Buying Price of FFB & $\mathrm{IDR} / \mathrm{Kg}$ & $1,030.41$ & $1,197.89$ & $1,067.19$ & 986.83 & $1,316.27$ & $1,005.76$ & $1,581.24$ & $1,257.69$ \\
\hline Wage of Labor & $\mathrm{IDR} / \mathrm{Kg}$ & 25 & 27 & 28 & 32 & 36 & 40 & 43 & 45 \\
\hline Transportation cost & $\mathrm{IDR} / \mathrm{Kg}$ & 27 & 30 & 34 & 35 & 36 & 37 & 38 & 38 \\
\hline Depreciation & $\mathrm{IDR} / \mathrm{Kg}$ & 36.91 & 42.54 .00 & 38.79 & 37.10 .00 & 46.99 & 39.17 .00 & 56.44 .00 & 46.73 \\
\hline Selling Price of FFB & $\mathrm{IDR} / \mathrm{Kg}$ & $1,230.41$ & $1,417.89$ & $1,292.9$ & $1,236.83$ & $1,566.27$ & $1,305.76$ & $1,881.24$ & $1,557.69$ \\
\hline Profit Margin & $\mathrm{IDR} / \mathrm{Kg}$ & 111.09 & 120.46 & 121,21 & 145.90 & 131.01 & 183.83 & 162.56 & 170.27 \\
\hline Marketting Margin & $\mathrm{IDR} / \mathrm{Kg}$ & 200 & 220 & 225 & 250 & 250 & 300 & 300 & 300 \\
\hline \multicolumn{10}{|l|}{ Firms } \\
\hline Buying Price of FFB & $\mathrm{IDR} / \mathrm{Kg}$ & $1,230.41$ & $1,417.89$ & $1,292.9$ & $1,236.83$ & $1,566.27$ & $1,305.76$ & $1,881.24$ & $1,557.69$ \\
\hline Selling price of CPO & $\mathrm{IDR} / \mathrm{Kg}$ & $6,898.54$ & $7,787.83$ & $7,401.49$ & $7,101.9$ & $8,287.98$ & $6,926.26$ & $7,516.97$ & $8,035.31$ \\
\hline transportation Cost & $\mathrm{IDR} / \mathrm{Kg}$ & 128 & 130 & 130 & 132 & 135 & 138 & 149 & 153 \\
\hline Wage of labor & $\mathrm{IDR} / \mathrm{Kg}$ & 50 & 58 & 63 & 75 & 80 & 85 & 90 & 95 \\
\hline profit Margin & $\mathrm{IDR} / \mathrm{Kg}$ & $5,490.13$ & $6,181.94$ & $5,915.59$ & $5,658.07$ & $6,506.71$ & $5,397.5$ & $5,396.73$ & $6,229.62$ \\
\hline Total of Marketting Cost & $\mathrm{IDR} / \mathrm{Kg}$ & 418 & 465 & 502 & 529 & 576 & 583 & 650 & 653 \\
\hline $\begin{array}{l}\text { Total Of Marketting } \\
\text { Margin }\end{array}$ & IDR/Kg & $6,068.13$ & $6,789.94$ & $6,583.59$ & $6,375.07$ & $7,271.71$ & $6,220.5$ & $6,285.73$ & $7,127.62$ \\
\hline Total Profit Margin & $\mathrm{IDR} / \mathrm{Kg}$ & 6,156 & 6,962 & 6,53 & 6,181 & 7,289 & 5,917 & 6,412 & 6,875 \\
\hline $\begin{array}{l}\text { Marketting Of efficiency } \\
(\%)\end{array}$ & $\%$ & 33.96 & 32.83 & 38.81 & 42.75 & 36.81 & 44.67 & 34.55 .00 & 41.95 \\
\hline
\end{tabular}

2) Profit Margin: The marketing system will be more efficient if the profit margin is higher, with criteria are: If $\mathrm{Pb}_{\mathrm{i}}+\mathrm{C}_{\mathrm{i}}<\mathrm{PM}_{\mathrm{i}}$ where the price of producer level and marketing cost is less than profit margin then the marketing system is efficient and If $\mathrm{Pb}_{i}+\mathrm{C}_{1}>\mathrm{PM}_{\mathrm{i}}$ where the price of producer level and marketing cost is less than marketing margin, then the marketing system is inefficient

The result of profit margin calculation in Table 2 shows that the profit margin received by the factory is more significant than that received by the farmer of FFB, where 
the profit obtained by the factory is IDR.5, 400 to IDR. 6, 500 whereas the profits at the farmers level only ranged from IDR.280 to IDR. 600. In general, the marketing system of FFB in PASBAR is inefficient because the price at the producer level and the marketing cost is higher than the profit margin obtained, only the profit margin at the factory level is higher than the purchase price of FFB and its marketing costs.

3) Farmer's share: If the value of the percentage of farmer share approach 100 percent, it is called more efficient but if the percentage of farmer share approach to zero, it implies the condition of marketing activities are inefficient. The results of farmer share calculation indicate that the share received by farmers is small (on average 60\%). This indicates that the condition of the FFB marketing system in PASBAR is inefficient because farmers only get less than $70 \%$ of the share they receive from the FFB marketing activity.

4) Marketing Efficiency $(E P)$ : A marketing channel is assessed efficiently if the marketing efficiency value is inferior to one $(\mathrm{EP}<1)$. Table 2 shows that the TBS marketing system in West Pasaman is inefficient as the value of marketing efficiency is higher than one. Generally, it can be said that TBS marketing system in West Pasaman Regency is not efficient regarding marketing margin, profit margin, and value of marketing efficiency.

\section{Price Efficiency}

Each time series data used in this study has stationary problems. The concept used to test the stationary of a time series data is unit root test. If time series data is not stationary, then it can be said that the data faces the root problem of the unit. Unit root test by one variable both independent and dependent variable was conducted by using Augmented Dickey-Fuller (ADF) test. With hypothesis:

$H 0: \beta=0$ (The data is not stationary on level)

$H 1: \beta=0$ (The data is stationaryon level)

If the test results obtained is $p$-value $<\alpha$, then the hypothesis $\mathrm{HO}$ is rejected and, it can be stated that the data is stationary at the the Table 3 is the result of unit root test at the level by using log-linear model.

TABLE III

STATIONERY LEVEL TEST

\begin{tabular}{|c|c|c|c|c|}
\hline Variables & t-stat & $\begin{array}{c}\text { t-crit } \\
(\mathbf{5 \%})\end{array}$ & Probability & Interpretation \\
\hline $\log (\mathrm{Pp})$ & -2.453618 & -2.894332 & 0.1304 & $\begin{array}{c}\text { Data is not } \\
\text { stasionary }\end{array}$ \\
\hline $\log (\mathrm{Pe})$ & -7.693974 & -2.894332 & 0.0000 & Stasionary data \\
\hline
\end{tabular}

Where: $P p=F F B$ selling price at farmer level $(I D R / K g)$

$$
\mathrm{Pe}=\mathrm{CPO} \text { export price } \mathrm{FOB}(\mathrm{IDR} / \mathrm{Kg})
$$

From Table 3 at the level showing non-stationary data at the buying price of the farmers' level is marked by a significant $\mathrm{P}$-value of $5 \%$ real level while the export rate price is stationary, where P-value is small from the real level of $5 \%$. Due to the existence of one variable that is not stationary at the same level, the next step is to test the root of the unit on the first difference.

The results obtained in Table 4 from the stationary test results on first difference shows that both variables are stationary at first difference so that it has fulfilled the requirement to obtain long-term relationship. Then the next test is followed by co-integration testing. With hypothesis: $H 0: \beta=0$ (The data is not stationary on the first difference) $H 1: \beta \neq 0$ (The data is stationary on the firt difference)

TABLE IV

FIRST DIFFERENCE TEST

\begin{tabular}{|l|l|l|l|l|}
\hline Variables & t-stat & $\begin{array}{l}\text { t-crit } \\
(\mathbf{5 \%})\end{array}$ & Probability & Interpretation \\
\hline DLog(Pp) & & $\begin{array}{l}- \\
2.894716\end{array}$ & 0.0000 & Stasionary data \\
& & - & 0.0000 & Stasionary data \\
\hline DLog $(\mathrm{Pe})$ & - & - & & \\
\hline & 10,51849 & 2.895109 & & \\
\hline
\end{tabular}

Co-integration tests are used to provide an early indication that the model used has a long-term relationship. The result of the co-integration test is obtained by forming the residual obtained by categorizing regression independent variable to a dependent variable by OLS. The residual must be stationary at the level to be said to have co-integration. So the model of the regression equation for the short term is (see Table.5). With hypothesis:

$\mathrm{H} 0: \mu=1$, meaning there is no cointegration $\mathrm{H} 1: \mu \neq 1$, meaning there is cointegration

TABLE V

REGRESSION MODEL FOR SHORT TIME

\begin{tabular}{|c|c|c|c|}
\hline Variables & Coefficient & t-stat & probability \\
\hline $\mathrm{c}$ & 5.333435 & 12.62856 & 0.0000 \\
\hline $\log (\mathrm{Pe})$ & 0.233554 & 4.946278 & 0.0000 \\
\hline
\end{tabular}

Based on the regression coefficients obtained in Table 4, the following regression model for short time equations (13) can be made:

$$
\log (p p)=5,33+0,23 \log (p \theta)
$$

From the short run regression equation shows that the value of the independent variable regression coefficient is positive dan value of 0.23 indicates that the price transmission elasticity is small from $1(\mathrm{Et}<1)$. It can be interpreted that if there is a change of CPO export price of $1 \%$ then result in FFB selling price at farmer level small than $1 \%$. This condition indicates FFB's marketing system at the farmers' level in the short run is inefficient.

This indicates that the value of Error Correction Term (ECT) on the model is significant at 5\% and marked negative.

TABLE VI

AUGMENTED DICKEY-FULLER ROOT LEVEL TEST RESULTS ON RESIDUAL QUESTIONS

\begin{tabular}{|c|c|c|c|c|}
\hline Variable & Method & t-stat & t-crit (5\%) & Probability \\
\hline ECT & ADF & -3.840717 & -2.900670 & 0.0039 \\
\hline
\end{tabular}

The ECM estimation results show that in the short and long runs, the variables of $\mathrm{CPO}$ export prices significantly at $\alpha=10 \%$ influence FFB selling prices at farmers' level and the independent variable regression coefficient is positive and value of 0.037960 indicates that the price transmission 
elasticity is small from $1(\mathrm{Et}<1)$. It can be interpreted that if there is a change of CPO export price of $1 \%$ then result in FFB selling price at farmer level small than $1 \%$. Moreover, ECT coefficient indicates that the difference in FFB selling price at the farm level with the FFB selling price at the equilateral exporter level of 0.163173 will be adjusted within a month to achieve long-term balance.

TABLE VII.

THE RESULTS OF LONG-TERM ECM REGRESSION ESTIMATION

\begin{tabular}{|c|c|c|c|}
\hline Variable & Coefficient & t-stat & Probability \\
\hline $\mathrm{c}$ & 0.0015 & 0.486769 & 0.6277 \\
\hline $\mathrm{D}(\log (\mathrm{Pe})$ & 0.037960 & 1.885963 & 0.0627 \\
\hline $\mathrm{ECT}(-1)$ & -0.163173 & -2.817173 & 0.0060 \\
\hline
\end{tabular}

Based on the ECM regression coefficients obtained in Table 7, the following ECM regression equations can be made

$$
D(\log (p p))=0,0015+0,038 D(\log (F e))-0,1632 E C T(-1)
$$

ECM estimates show that in the short run and long run CPO export price of FOB significantly affects FFB selling price at farmer level. The value of the independent variable is positive, and value of 0,038 indicates that price transmission elasticity large from 1 (Et> 1). It can be interpreted that if there is a change in $\mathrm{CPO}$ export price of $1 \%$ then result in FFB selling price at farmer level greater than $1 \%$ in the short term, but will lead to a long-term balance of 0.163173 which will be adjusted within one month. It can be seen in Figure 7 that ECT has been stationary.

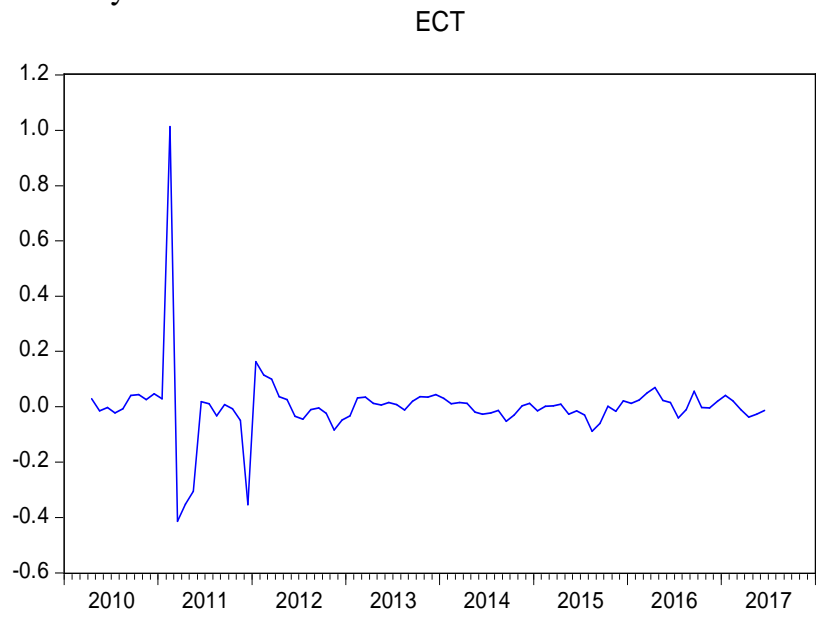

Fig 7. Error Correction Term is Stationary

To see the economic implication of the research findings, the elaboration should be based on three aspects, i.e., Supply Chain Condition, The existence of Marketing Margin, Price efficiency, and then Marketing efficiency

\section{CONCLUSIONS}

This research has endeavored to prove the hypothesis that the market condition that has existed at the marketing level of FFB in PASBAR for 17 years is not efficient. Several efficiency indicators determine it, i.e.: (i). $\mathrm{Pbi}<\mathrm{Mmi}$;
(ii).Pbi+Ci > Pmi; (iii) FS average $60 \%$, its not close to $100 \%$ (iv) ME $>1$ (v) Et $<1$. This inefficiency implies that purchase price received by the farmers is relatively low and therefore inadequate. Further research is required to design the efficiency of supply chain model of FFB in West Sumatera.

The contribution of this research to West Sumatera Province is the importance of the government's active role in monitoring and controlling the selling price of FFB. It starts from the level of farmers as the supplier of FFB to the factory level so that all actors in the FFB supply chain in West Sumatera Province. It can benefit the selling price of FFB with increasing prices of palm oil in the International Market.

\section{REFERENCES}

[1] Central Bureau of Statistics, "Gross Domestic Product by Industrial Origin 2012-20116",2016.

[2] Central Bureau of Statistics. Regency of West Pasaman In Figures. 2016.

[3] Directorate General of Plantation. "Statistics Indonesia of oil palm commodities"2013-2015, Jakarta, 2014.

[4] Arianto, E, "Analysis of Palm Oil Price, Review of Coal Integration of Vegetable Oil and Petroleum Price," Journal of IPB. Vol.7, No.1, 2010.

[5] Abidin, Z, "Analysis of Indonesia's Palm Oil Exports (CPO)," Journal. Application Management Vol. 6, Number 1. Faculty of Economics University. Brawijaya, 2008.

[6] Ernawati,"Export Tax and Its Impact on Palm Oil Indonesia to India.” Informatics of Agriculture. Vol.16, No. 2, 2007.

[7] Mohammadi, S., F. M. Arshad., B.K. Bala and A. Ibragimov. "System Dynamic Analysis of the Determinants of the Malaysian Palm oil Price."American Journal of Applied Sciences 12 (5): 355362. 2015.

[8] Agustian, A, and P.U. Hadi. "Analysis of export Dynamics and comparative advantage of palm oil (CPO)." Center for Agricultural Socio-Economic Studies. IPB. Bogor, SOCA: 263-274, ISSN 1411 7177, Volume 4.number 3. 2004.

[9] Bisuk, P."Analysis of Trade and Elasticity of International CPO Price Transmission Against Palm Oil FFB Price." Department of Agricultural Socioeconomics, University of North Sumatra. 2009

[10] Tan, Firwan.'Price Efficiency in Vertical Integrated Market Study on Market of Natural Rubber Industry Products of Indonesia".Journal of Management and Development, Vol 4, No.1. 2005.

[11] Kustiari, R and S. Nuryati. "Dynamics of Agriculture and Rural Development: Challenges and Opportunities for Increasing Farmers Welfare." Center for Agriculture.Socio-Economic and Policy Studies, Agriculture Department. Bogor. 2008.

[12] Franco, C.J., M.C. Ochoa, and A.M. Florez, "System Dynamics approach to biofuels in Colombia."Proceedings of the 27th International Conference of the System Dynamics Society, Albuquerque, New Mexico, USA, pp: 1-171. 2009.

[13] Mohammed, N. "Concentration and Competition in Dual Banking Industry." A structural approach. Jurnal Ekonomi Malaysia 50 (2). 2016

[14] Center for Populist Economic Studies of Gadjah Mada University (PUSTEK-UGM). "Self-employed Smallholders in the Palm Oil Industry in Indonesia.”UGM. 2009.

[15] Guritno, Public Economics. Yogyakarta: BPFE-Yogyakarta. 1993

[16] Avenzora, A. "Analysis of Productivity and Efficiency of Textile and Textile Products Industry in Indonesia Thun 2002-2004”. Thesis Graduate of Economics University of Indonesia, JKT. 2008.

[17] Coelli, T.J., D.S.P. Rao, and G.E. Battese. "An Introduction to Efficiency and Productivity Analysis"Kluwer Academic Publisher. Boston. 1998.

[18] Meyers, R.A." Complex Systems in Finance and Econometrics". 1st Edn., New York, Springer, ISBN- 10: 1441977007. pp: 406. 2011

[19] Asmarantaka." Course Module Agribusiness Product Course". Department of Agroindustry. Economics and Management, Bogor Agricultural. University, Bogor. 2009. 
[20] Kusnadi, N., Tinaprilla, N., Susilowati, S. H., \&Purwoto, "A. Analysis of the efficiency of rice farming in several rice production centers in Indonesia" Journal of Agro Economics 29 (1): 25-48. 2011

[21] Karantininis, K., Katrakylidis K. And Persson, M. "Price Transmission In The Swedish Pork Chain: Asymmetric NonLinear." Paper P resented At TheEaae 2011 Congress. 2011

[22] Irawan, B." Price Fluctuations, Price Transmission And Margin Of Vegetables And Fruit Marketing". Journal of Agricultural Policy Analysis. Volume 5 No. 4, December 2007: 358-373. 2007.

[23] Gujarati, D. "Basic Econometrics," Sumarno Zain's translation. Erlangga, Jakarta. 2003.

[24] Nachrowi, Hardius. "Popular Approach and Practical Econometrics for Economic and Financial Analysis”. Jakarta. Indonesia. 2006.

[25] Engle, Robert F. and C.W.J. Granger. Cointegration and error correction: Representation, estimation, and testing, Econometrica 55, 251-276. 1987.

[26] Francisco, C. Grain Price and Volatility Transmission From International to Domestic Market in Developing Countries. Selected Paper for Presentation at 2015 at Agricultural and Applied Economic Association and Western Agricultural Economics Association Annual Meeting, San Francisco. 2015
[27] Kohls R.L danUhl, J.N. "Marketing of Agricultural Products." 9thEdition.New Jersey. Prentice Hall. 2002

[28] Tukan, C.J, et. al. "Marketing of timber from farmers' land in Prov. Lampung". Http: // wordagroforest. Master of Development Studies Institute of Technology Bandung. 2001

[29] Tan Syamsurijal and Tan Firwan, "Indonesian Crude Palm Oil Export Performance during the Period (1990Q1-2015Q4)", published byMerit Research Journal of Agricultural Science and Soil Sciences (ISSN: 2350-2274) Vol. 5(8) pp. 152-165, August 2017.

[30] Tan Firwan, "Fishermen Economic Development Management System in The South Coastal District of West Sumatra Indonesia" Proceedings of SOCIOINT14- International Conference on Social Sciences and Humanities, pages: 196-208, 8-10 September 2014 Istanbul, Turkey, ISBN: 978-605-64453-1-6.

[31] Andayani, W. 2007. Marketing Efficiency analysis of Chasew Nuts in Wonogiri. Journal Akta Agrois, 10(10): 57-58.

[32] Roesmawaty, H. 2011. Marketing Efficiency analysis of Banana Lengkiti- Ogan Komering Ulu Regency. Journal Agribisnis. 3(5) : 1-9.

[33] Downey, W.D, S.P. Erickson. 1992. Management of Agribisnis. Erlangga. Jakarta. 